\title{
The Rate of Elaboration of the Extracellular Polysaccharide, Pullulan, during Growth of Pullularia pullulans
}

\author{
By B. J. CATLEY* \\ Department of Biochemistry, University of Miami School of Medicine, \\ Miami, Florida, 331 52, U.S.A.
}

(Received 24 November 1972; revised 12 March 1973)

SUMMARY

During the growth of the yeast-like fungus Pullularia pullulans, the pattern of glucose utilization by the cell varied from a complete inability to elaborate extracellular polysaccharide to the diversion of almost two-thirds of metabolized glucose to pullulan elaboration. The effects of carbon and nitrogen levels on this changing pattern during growth were examined. These investigations indicated that the elaboration of pullulan, and the onset of a morphological change of Pullularia from a filamentous to a yeast-like form, were related to the availability of nitrogen, and not carbon, in the growth medium.

\section{INTRODUCTION}

Pullulan, an extracellular $\alpha$-glucan elaborated by the yeast-like fungus Pullularia pullulans, is predominantly $\alpha$-maltotriose linked endwise through I,6-bonds (Wallenfels, Keilich, Bechtler \& Freudenberger, 1965). During an investigation into the ability of the organism to elaborate pullulan, Catley (I97 $b$ ) observed that, at an early phase of growth, there appeared to be little or no production of the polysaccharide, whereas at a later stage pullulan was synthesized. These analyses were made at two arbitrarily chosen stages of growth. This communication describes changes in the organism's patterns of glucose utilization and polysaccharide elaboration which occur throughout the course of its growth, and relates these patterns to the availability of nitrogen and carbon in the medium.

\section{METHODS}

Quartermaster strain no. 3092 of Pullularia pullulans, kindly supplied by E. T. Reese of the U.S. Army Natick Laboratories, Natick, Massachusetts, U.S.A., was maintained and grown as described previously (Catley, I97I $a$ ). The carbon source of the culture medium was glucose at 35,140 or $560 \mathrm{~mm}$; nitrogen sources were $0,4.5$ or $22.5 \mathrm{~mm}$-ammonium sulphate. All cultures contained $0.4 \%$ yeast extract (Difco). Rates of uptake of glucose and extracellular polysaccharide elaboration were measured as previously described (Catley, I97 I $b$ ). Samples of cells, withdrawn from cultures growing under different nutritional conditions, were washed and suspended in a standard uptake medium containing: glucose, I $4 \mathrm{~mm}$; $0.008 \mu \mathrm{Ci}$ of uniformly labelled $\left[{ }^{14} \mathrm{C}\right]$ glucose (New England Nuclear Corp.)/ml; $\mathrm{K}_{2} \mathrm{HPO}_{4}$, $29 \mathrm{~mm} ; \mathrm{NaCl}, \mathrm{I} 7 \mathrm{~mm} ; \mathrm{MgSO}_{4} .7 \mathrm{H}_{2} \mathrm{O}, 0.8 \mathrm{~mm} ;\left(\mathrm{NH}_{4}\right)_{2} \mathrm{SO}_{4}, 4.5 \mathrm{~mm}$, which was then adjusted to $\mathrm{pH} 5.0$ with $\mathrm{HCl}$. The incorporation of ${ }^{14} \mathrm{C}$, measured for $90 \mathrm{~min}$, was linear for the first hour and often for the total period. Extracellular polysaccharide elaboration was determined

* Present address: Department of Brewing and Biological Sciences, Heriot-Watt University, Edinburgh, EHI IHX. 
at the same intervals and, when it occurred, was linear after an induction period (Catley, 1972) of about $30 \mathrm{~min}$. Each uptake or elaboration rate, presented in Fig. I to $3(b)$, is therefore based on four ${ }^{14} \mathrm{C}$ analyses. In addition, data presented in these Figures are the combination of analyses from two cultures grown under identical conditions, but with different sampling times. Periodically the pullulan content of the extracellular polysaccharide was determined by hydrolysing the elaborated polymer with pullulanase (Catley, 197I $a$ ). The action of amyloglucosidase from Aspergillus niger (Abdullah, Fleming, Taylor \& Whelan, 1963) on the polymer was also examined. The chromatographically separated maltrotriose, produced by pullulanase, or glucose, released by amyloglucosidase, accounted for $80 \%$ of the elaborated polymer.

Glucose was measured by the glucose-oxidase reagent (Lloyd \& Whelan, 1969) and growth was recorded as the dry weight of cells (Catley, I97I $a$ ). Extracellular pullulan was measured by a technique involving precipitation with alcohol, digestion with pullulanase, and measurement of the maltotriose released (Catley, I97I $a$ ).

Cells were fractionated into yeast and hyphal forms by centrifugation on a mannitol gradient $(0.12 \mathrm{M}$ to $\mathrm{I} .5 \mathrm{M})$ at $\mathrm{I} 00 \mathrm{~g}$ for $15 \mathrm{~min}$ at room temperature and were then washed twice with distilled water before use.

\section{RESULTS}

The organism's ability, as a rate/mg dry wt cells, to assimilate labelled carbon from $\left[{ }^{14} \mathrm{C}\right]$ glucose and to elaborate pullulan over the major period of the growth cycle is expressed in Fig. I. The culture medium contained $140 \mathrm{~mm}$-glucose and $4.5 \mathrm{~mm}$-ammonium sulphate. The organism's potential for producing pullulan varied considerably during growth from a complete inability to elaborate extracellular polysaccharide at $\mathrm{I} 2 \mathrm{~h}$ to the diversion of approximately two-thirds of metabolized glucose to pullulan production at $37 \mathrm{~h}$. The rate of assimilation of glucose also varied. Increasing either the glucose or ammonium sulphate concentration fourfold or decreasing it to $\mathrm{I} / 4 \mathrm{did}$ not alter the ${ }^{14} \mathrm{C}$-distribution pattern of the cells over the $90 \mathrm{~min}$ period used in the uptake analysis. In the period used for determining assimilation and elaboration rates the increase in weight of cells suspended in the uptake medium was no more than I0 \% when sampled at the fastest phase of growth and considerably less at others. An environment of $\mathrm{pH} 5$ ensured that pullulan elaboration was expressed whenever possible (Catley, I97I $b$ ). The results obtained from these studies of the uptake medium indicate that for the short assay period the composition of the uptake medium did not alter the distribution of ${ }^{14} \mathrm{C}$ between cell and extracellular polysaccharide.

Despite a I6-fold change in the initial glucose concentration from 35 to $560 \mathrm{mM}$, the growth characteristics of Pullularia, at least over the first $30 \mathrm{~h}$, remained similar (Fig. 2a, b). The distribution pattern of glucose utilization seemed little affected by the external glucose concentration.

The change in growth rate over the first $24 \mathrm{~h}$ was accompanied by a morphological change. The inoculum from a 48 or $72 \mathrm{~h}$ culture was yeast-like, but in fresh medium rapidly became filamentous, thereafter reverting to the original single-cell form. At this transitional stage the two forms were separated by centrifugation on a mannitol gradient. The hyphal cells sedimented more rapidly and only the yeast cells produced extracellular polysaccharide.

A fivefold increase or complete removal of the ammonium ion (leaving only yeast extract as nitrogen source) gave the results shown in Fig. 3(a) and (b). Table I describes the cell density at which the organism, grown under different conditions of nutrition and environmental $\mathrm{pH}$, reached a maximum in glucose utilization rate. From microscopic observation of the cells during growth, the rate of glucose assimilation is probably a monitor of the cell's 


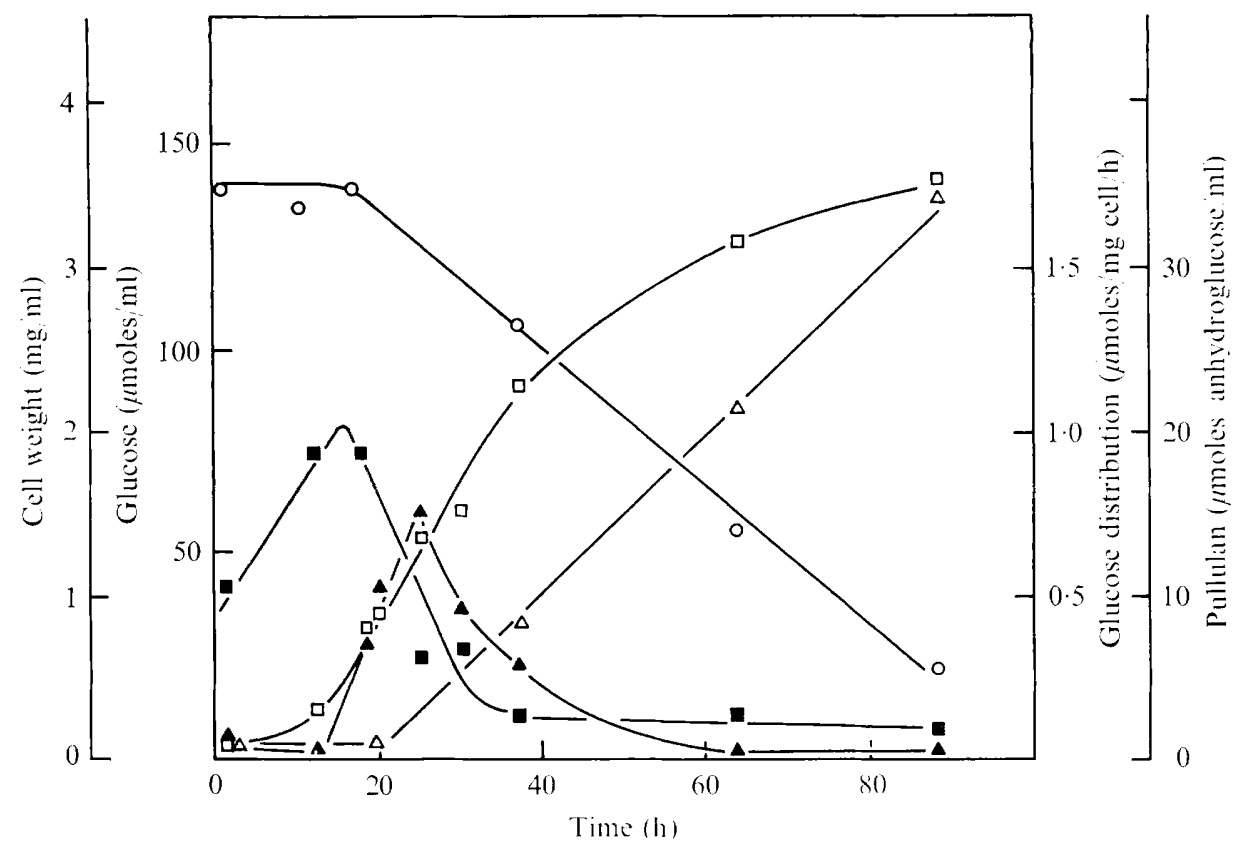

Fig. 1. Growth of Pullularia pullulans in medium containing $140 \mathrm{~mm}$-glucose and $4.5 \mathrm{~mm}$-ammonium sulphate. $\square$, Dry cell wt $(\mathrm{mg} / \mathrm{ml}) ; \bigcirc$, extracellular glucose $(\mu \mathrm{moles} / \mathrm{ml}) ; \triangle$, extracellular pullulan $(\mu$ moles anhydroglucose $/ \mathrm{ml}) ; \mathbf{\square}$, rate of ${ }^{14} \mathrm{C}$ accumulation expressed in terms of glucose assimilation $(\mu$ moles $/ \mathrm{mg}$ cell $/ \mathrm{h}) ; \boldsymbol{\Lambda}$, rate of extracellular polysaccharide elaboration $(\mu$ moles anhydroglucose/mg cell/h).

Table I. Effect of pH, nitrogen and glucose levels of culture medium on the cell concentration where the rates of glucose utilization and pullulan elaboration were maximal in cultures of Pullularia

\begin{tabular}{|c|c|c|c|c|c|c|c|}
\hline \multirow[t]{3}{*}{ 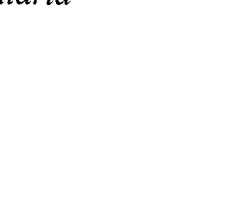 } & \multicolumn{7}{|c|}{ Initial concentrations (mM) of glucose and $\left(\mathrm{NH}_{4}\right)_{2} \mathrm{SO}_{4}$} \\
\hline & \multicolumn{6}{|c|}{$\mathrm{pH}$ of cultures unadjusted } & $\begin{array}{l}\text { Initial } \mathrm{pH} \\
\text { adjusted } \\
\text { to } 5 \cdot \mathrm{I}\end{array}$ \\
\hline & Glucose & 35 & 140 & 560 & 140 & 140 & I 40 \\
\hline $\begin{array}{l}\text { Cell density* at } \\
\text { maximal glucose }\end{array}$ & $\left(\mathrm{NH}_{4}\right)_{2} \mathrm{SO}_{4}$ & $4 \cdot 5$ & $4: 5$ & $4 \cdot 5$ & 0 & $22 \cdot 5$ & $4 \cdot 5$ \\
\hline utilization rate & & 0.4 & 0.5 & 0.5 & 0.15 & 0.8 & 0.5 \\
\hline $\begin{array}{l}\text { Cell density* at } \\
\text { maximal pullulan } \\
\text { elaboration rate }\end{array}$ & & $I \cdot 7$ & $I \cdot 4$ & $I \cdot 6$ & 0.4 & $2 \cdot 7$ & $\mathrm{I} \cdot 4$ \\
\hline
\end{tabular}

morphological state, reflecting a faster growth for the filamentous form of Pullularia. If this change is indeed monitored by the rate of glucose uptake per unit weight of cell, the levels of nitrogen, but not carbon, determine the cell density at which this maximum utilization rate is achieved (Table $\mathrm{I}$ ).

Pullulan was produced with the onset of a decrease in culture growth rate in each of the five nutritional conditions presented (Fig. I to 3). However, pullulan production declined at a later stage of growth. The nitrogen level of the medium seemed to determine pullulan 

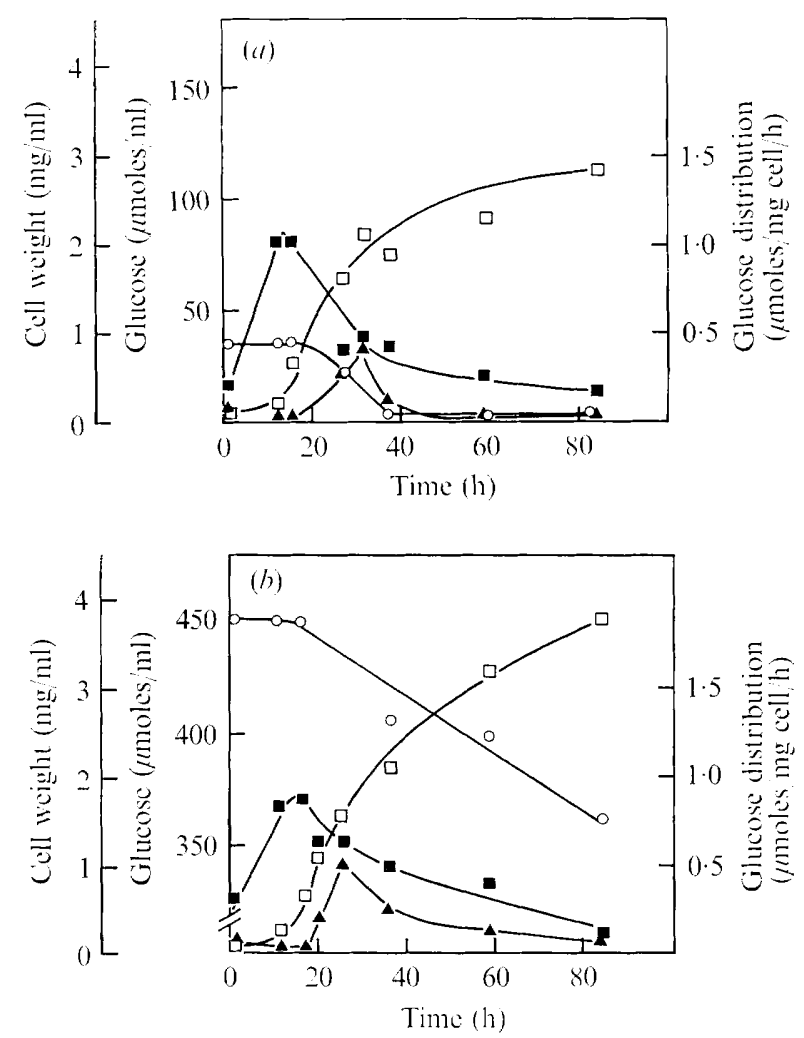

Fig. 2. Growth of Pullularia pullulans in medium containing initial glucose concentrations of (a) $35 \mathrm{~mm}$; (b) $560 \mathrm{~mm}$. For key see Fig. I.

Table 2. Utilization of pullulan by Pullularia growing in conditions of glucose limitation*

$\begin{array}{cccc}\begin{array}{c}\text { Sample } \\ \text { time (h) }\end{array} & \begin{array}{c}\text { Cell } \\ \text { density }\end{array} & \begin{array}{c}\text { Pullulan } \\ \text { (c.p.m./ml) }\end{array} & \begin{array}{c}\text { Cells } \\ \text { (c.p.m./ml) }\end{array} \\ 0 & 0 & 1660 & 0 \\ 19 & 0.8 & 1522 & 17 \\ 42 & 2 \cdot 0 & 1530 & 16 \\ 63 & 1.8 & 1350 & 19 \\ 87 & 1 \cdot 9 & 1390 & 16\end{array}$

* Medium containing glucose (Iо $\mathrm{mM}$ ) and $\left[{ }^{14} \mathrm{C}\right]$ pullulan (Io mM-anhydroglucose).

$\dagger \mathrm{mg}$ dry $\mathrm{wt} / \mathrm{ml}$.

formation since the maximum pullulan-elaboration rate for cultures with high initial levels of nitrogen occurred at a cell density some 6.7 times greater than those relying solely on yeast extract for nitrogen (Table $\mathrm{I}$ ).

The distribution of ${ }^{14} \mathrm{C}$ incorporation into the cells and pullulan was examined with cultures grown in medium with an initial $\mathrm{pH}$ of $5 \cdot \mathrm{I}$ instead of $7 \cdot 4$. Although the $\mathrm{pH}$ fell to 2.9 during the 3 days of growth there were essentially no differences from those cells commencing growth at the higher $\mathrm{pH}$, and the cell densities at which maximum glucose utilization and pullulan elaboration rates occurred were the same (Table I). 

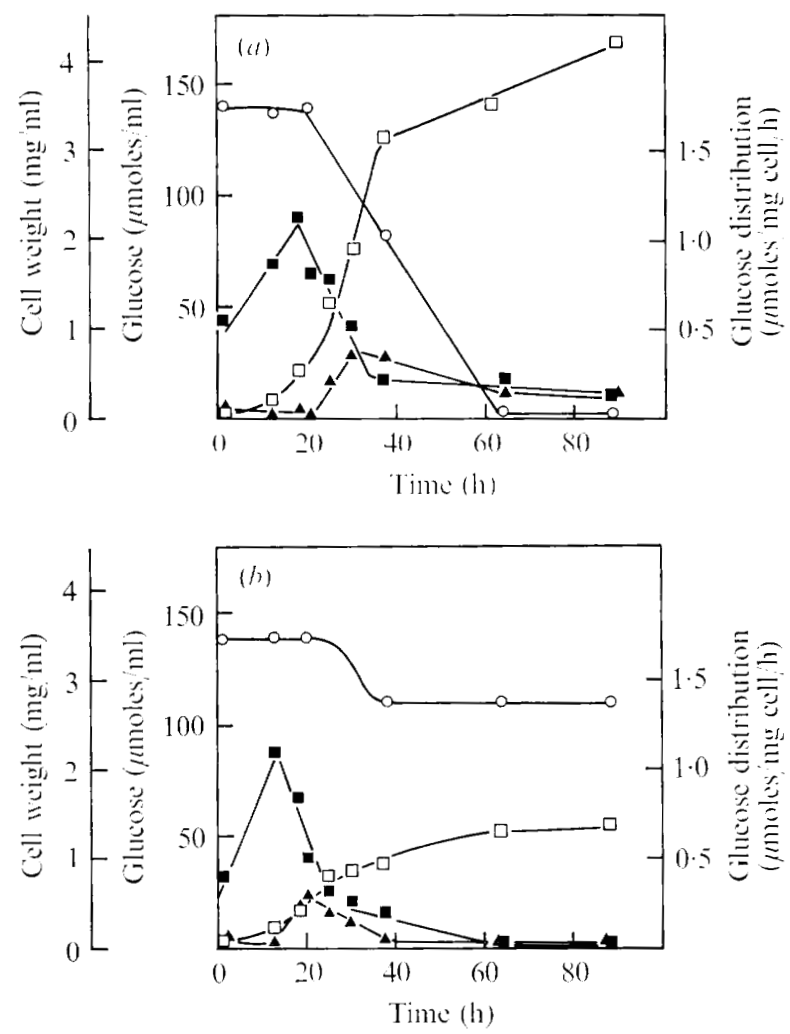

Fig. 3. Growth of Pullularia pullulans in medium containing initially (a) 22.5 mM-ammonium sulphate or $(b)$ no ammonium sulphate. For key see Fig. I.

The utilization of pullulan by Pullularia growing in conditions of glucose limitation was studied. In medium with initially $10 \mathrm{~mm}$-glucose (in contrast to the normal $\mathrm{I} 40 \mathrm{~mm}$ ) and containing $\left[{ }^{14} \mathrm{C}\right]$ pullulan, there was a negligible uptake of radioactive carbon by the cells and little disappearance of label from the medium (Table 2).

\section{DISCUSSION}

The appearance of extracellular pullulan does not parallel the increase in cell mass of growing Pullularia cultures (Catley, I97I $a, b$ ); the accumulation of extracellular pullulan is linear with time during a phase of the culture where there is rapid multiplication. If ability to elaborate pullulan, once initiated, remained constant, extracellular polysaccharide should accumulate at an increasing rate over this period. Elaboration of pullulan during the major growth period might vary or pullulan might be both produced and reutilized by the organism, and an imbalance of these two processes would lead to the accumulation of the polysaccharide observed. Pullularia does not normally metabolize pullulan (Catley, I970; Table 2). Thus in conditions of glucose limitation the cells seemed unable to utilize their own extracellular product; and this alternative rationale for the observed rate of pullulan elaboration must be dismissed.

Pullulan was not elaborated at all stages of growth, and it is clear from the results presented here and earlier (Catley, 197r $b$ ) that the level of nitrogen present in the medium is 
critical to glucose utilization patterns. The change to the yeast form indicates the point at which the ability to elaborate pullulan appears. The inhibition of polysaccharide elaboration observed at a later phase of growth is again related to nitrogen availability. This decrease contrasts with observations on other micro-organisms. Thus in Escherichia coli (Sigal, Cattaneo \& Segel, I964) limitation in both sulphur and nitrogen sources leads to an accumulation of internal polysaccharide reserves.

This work was supported by funds from the National Science Foundation (Grant GB 30356), and the excellent technical help of Anne de Bont.

\section{REFERENCES}

Abdullah, M., Fleming, I. D., Taylor, P. M. \& Whelan, W. J. (1963). Substrate specificity of the amyloglucosidase of Aspergillus niger. Biochemical Journal 89, 35P-36P.

CATLEY, B. J. (1970). Pullulan, a relationship between molecular weight and fine structure. FEBS Letters ro, I90-193.

CATLEy, B. J. (I97I $a$ ). Utilisation of carbon sources by Pullularia pullulans for the elaboration of extracellular polysaccharides. Applied Microbiology 22, 64I-649.

CATLEY, B. J. (I97 $b$ ). Role of $\mathrm{pH}$ and nitrogen limitation in the elaboration of the extracellular polysaccharide pullulan by Pullularia pullulans. Applied Microbiology 22, 650-654.

CATLEY, B. J. (1972). Pullulan elaboration, an inducible system of Pullularia pullulans. FEBS Letters 20, $174-176$.

Lloyd, J. B. \& Whelan, W. J. (1969). An improved method for enzymic determination of glucose in the presence of maltose. Analytical Biochemistry 3o, 467-470.

Sigal, M., CAtTANeo, J. \& Segel, I. H. (I964). Glycogen accumulation by wild-type and uridine diphosphate glucose pyrophosphorylase-negative strains of Escherichia coli. Archives of Biochemistry and Biophysics ro8, 440-45I.

Wallenfels, K., Keilich, G., Bechtler, G. \& Freudenderger, D. (1965). Untersuchungen an Pullulan. IV. Die Klärung des Strukturproblems mit physikalischen, chemischen und enzymatischen Methoden. Biochemische Zeitschrift 34r, 433-450. 